\title{
Revitalizing Mathematics Education Preparation in Nigeria for National Development: An Innovative View
}

\author{
Tella Adedeji ${ }^{{ }^{*}}$ \\ ${ }^{1}$ University of Ibadan, Science and Technology Education Department, Ibadan, NIGERIA \\ *CORRESPONDENCE: $\square$ dejtell@yahoo.com
}

\begin{abstract}
Mathematics education currently is not in a good phase as regard its product in term of marketability, teachers' quality, subject mastery, professional competent, pedagogical acumen among others. National development in the context of teacher preparation and other so called in Nigeria should be seen within perspective of overall progress because national development embodies the overall gross progress people achieve within the context of its economic, political and socio-cultural potential. It has since become an undisputable fact that education is one of the potent tool for social transformation for national development anywhere in the world and in all sphere of political system. It is therefore imperative to look critically at different ways to revitalize Mathematics education preparation in Nigeria with reference to national development and putting up various innovations and think-thank syndrome into pre-service teacher preparation.

Keywords: mathematics education preparation, national development, innovation and revitalization
\end{abstract}

\section{INTRODUCTION}

Teaching is a means to acquiring education. It involves some activities such as transmuting of information or knowledge, performance of tasks and enrichment of knowledge and beliefs through the interactions of the teachers and the learners. Teaching is classified into three acts: logical, strategic and institutional. Logical acts refer to such activities as explaining, inferring, concluding and giving evidence. This aspect of teaching is contents based. The strategic acts involve, such as motivating, encouraging, praising and disciplining (Amaele \& Amaele, 2003). Mathematics education refers to the policies and procedures designed to equip teachers with the knowledge, attitudes, behaviours and skills they require to perform their tasks effectively in the school and classroom (New World Encyclopedia, 2010).

Mathematics education is the specialized training given to world-be teachers in a formal school system, so as to equip and nurture them for the great task of teaching. Teacher's education connotes process of preparing teachers for professional roles of reflective practitioners (Achuonye, 2010). Mathematics education is very critical because qualitative education cannot be attained by any nation if the quality of the teacher is not enhanced. Ejima (2002) noted that the quality of a teacher is dependent on his or her preparation for professional role as distinct-practitioner.

In the teaching profession, the teacher constitutes a critical factor in the success of any educational system. Many laudable educational initiatives have failed mainly because they did not take due account of the "teacher factor". The quality of the teacher, to a large extent, determines the quality of the educational system (Rogers

\footnotetext{
Article History: Received 13 April $2018 \bullet$ Revised 27 May $2018 \bullet$ Accepted 2 July 2018

(C) 2018 The Author(s). Open Access terms of the Creative Commons Attribution 4.0 International License (http://creativecommons.org/licenses/by/4.0/) apply. The license permits unrestricted use, distribution, and reproduction in any medium, on the condition that users give exact credit to the original author(s) and the source, provide a link to the Creative Commons license, and indicate if they made any changes.
} 
1973). It should be recognized that production of quality teachers will enhance the consolidation of educational system in Nigeria.

Revitalizing mathematics' education is assumed will enhance quality teaching and better teachers' productivity and consolidation of the Nigerian educational system. As it has been rightly observed, it is not all Mathematics education and training programmes that aspire to the same high quality standard. In other words, some Mathematics education programmes in Nigeria cannot meet the yearnings and aspirations of contemporary Nigerian not to talk of taking them to the promise land in terms of national development. It is against this background, the National Policy on Education (2004:26) stated that "no education system can rise above the quality of its teachers." Hence, the teacher's job is so vital that it has been generally accepted to be the central organ of education.

A consideration of a stable, functional and revitalized educational system should involve consistent retraining of teachers for efficient implementation of the curriculum for Nigerian schools. Constant development and re-training of teachers will improve capability of teachers for efficient use of the curriculum, being the implementers of the educational programmes. As such, there is the need for teachers' re-training programmes and adequate supply of human and material resources for educational productivity and consolidation of the Nigerian educational system. Therefore, the concern of this paper is to consider the concept of revitalization as it affects teachers, efficient curriculum implementation by professionally trained teachers and curriculum innovation for qualitative teaching outcome in the $21^{\text {st }}$ century.

\section{REVIEW OF LITERATURE}

Revitalization, mathematics education and national development are the concepts that are key to the discussion in this paper. In the light of this, it is considered necessary to have them defined operationally. Revitalization means to give new life, vigor, vitality to education. It can also mean to impart new life or vigor to African education and or putting up efforts to revitalize it. It is the process of making something grow, develop or become successful again

To revitalized mathematics education for national development, some issues of concern such as concern for knowledge production and use of knowledge in production, concern for realigning mathematics education to the empowerment market, a concern for expanding teacher education, concern for partnership between higher education and the community, etc. To address these concerns, revitalization is very necessary. This have to come in form of reformation to enhance capacity to produce and use knowledge; reformation to reposition mathematics education to changes in the external environment; and reforms to expand the system. These reformation or revitalization is expected to lead to a more integrated system of preparing teacher across countries in Africa.

A teacher in the professional sense of the word is someone who attempts to help someone to acquire skills, attitude, ideas and knowledge that would create or influence desirable changes in the behaviours of the learners. He is the hub around which the entire education system revolves. Nwagwu, quoting Butts in Amaele and Amaele (2003) affirms that "man believes that education has power to set him free but everywhere he is in chain for want of good teachers". For the formal education sector to carry out its mandates effectively for the development of the state or nation, the place of the teachers cannot be overemphasized. In describing education as an agent of development Okorosaye- Orubite (1990) in Pulley (2010:13) states that, "education should transform the child into functional adult". To be functional according to him: the individual should be given the opportunity to develop his latent potentials to the fullest capabilities to enable him perform those functions (for his benefits and that of his society) for which he is naturally endowed and fitted in times of peace and war. In essence, education should enable the individual to perform to the best of his capabilities in the competitive world of survival of the fittest.

However, mathematics education and teacher training is often used interchangeably. The concept of training as used here needs to be explained to make for clearer understanding of its usage in mathematics education. Training according to Okeke (2004) connotes learning organized to achieve certain productive skills, development of technical ability, productivity or output, initiative and innovation in the business of teaching. Nakpodia and Urien (2011) in their part view mathematics education as the process which nurtures prospective teachers and update qualified teacher's knowledge and skills in the form of continuous professional development. Oyedeiji (2006) on his part defines Mathematics education as an amalgamation of institutionalized preparation or further education of persons who are engaged directly or indirectly in education activity. The identified three stages of mathematics education include initial teacher education, 
induction and continuing professional development. The initial mathematics education is provided by accredited Mathematics education institutions or units. Induction is the education and support given to newly qualified teachers in the first few years of teaching to help him or her develops a professional identity and further develops the basic competence not acquired during the initial mathematics education in school. This is mostly done by mentoring, peer network and input from education experts. Continuing professional development has to do with in-service education for practicing teachers which include seminars, conferences and workshops. It is therefore expected that high quality mathematics education programmers will enhance student's academic achievements and foster further national development.

\section{REVITALIZING MATHEMATICS EDUCATION IN THE LIGHT OF TRAINING}

There is way to talk about revitalizing Mathematics education that training will not be a part. This implies that training is germane to revitalization. The term "training" implies exercising some repetitive actions. It aims at developing limited ability or skill rather than the development of the entire personality (Tella, 2004). Training of teachers is the process of imparting to someone the skill to perform some operations which may be mental or physical, the acquisition of which may or may not be accompanied by understanding of the principles on which the operation depends (Schofield, 1974). It is also the process or a set of activities aimed at making a person efficient at the performance of a given task. In order words, it could be understood that doctors, lawyers and teachers are trained rather than being educated. Teachers are included here because, their preparation is directed towards acquisition of certain special skills, and the evidence of learning in the classroom, is the successful performance skills of the teacher termed pedagogue. In the teaching profession, the teacher constitutes a critical factor in the success of any educational system. Many laudable educational initiatives have failed mainly because they did not take due account of the "teacher factor". The quality of the teacher, to a large extent, determines the quality of the educational system (Rogers, 1973). It should be recognized that, production of quality teachers will enhance the consolidation of educational system in Nigeria. Therefore, training and re-training of teachers in English language will enhance quality teaching and better teachers' productivity and consolidation of the Nigerian educational system.

\section{MATHEMATICS EDUCATION CURRICULUM QUALITY AND IMPLEMENTATION}

The comprehensive nature of the secondary school curriculum necessitates the training and re-training of specialist teachers, especially in English Language. It should be noted that, there had been a rush for the expansion of facilities for training English language teachers in Nigeria since the late 1970s and between 1977 and 1985, efforts have been geared towards the raising of the quality and quantity of manpower needs for the efficient implementation of the curriculum and qualitative teaching outcome (Osokoya, 1997). Nigeria has a laudable educational system like many other countries of the world. Each country has its peculiar characteristics and thereby adopts its policies to meet its own social, economic, political and cultural needs (Fatile, 2005). As a result, each country need different strategies to realize the basic policies which are crucial to the development of education in the general education policies because of the pressing need for more sophisticated type of education. The National Policy on Education states the five objectives of education viz viza the building of: A free and democratic society; A just and egalitarian society; A united strong and selfreliant nation; A great and dynamic economy, and A land of bright and full opportunities for all citizens (NPE, 2004).

Two of the above objectives called for pragmatism of re-education. That is, practical or vocational aspects of education coupled with craft knowledge. This kind of educational ideas and objectives need be consolidated through effective re-training of professional teachers in English language. This will also help in determining the quality of teachers' productivity and teaching outcome. Teachers' productivity is an important factor in educational development and also a vital factor in consolidating the Nigerian educational system. Retraining of teachers determines the quality of the out-put and no nation can progress without the effective development and management of teachers (Sofoyeke, 2001). Therefore, training and re-training of English language teachers as a pre-condition for functional educational system in Nigeria is very necessary because English being a functional language has so many aspects which every qualified English language teacher should be able to master for effective teaching productivity.

The enhancement of qualitative teaching outcome will involve the improvement of the quality of English language teachers to meet the needs of the learners, fulfill educational goals and satisfy the need of the society at large. The major problem militating against the smooth running and consolidation of Nigerian system of 
education is the implementation. This may be due to lack of certain resources either human or material. There are some problems aligned with the 6-3-3-4 system of education; these include the curriculum problem. Although there is a well-defined curriculum on paper for the programme, but one cannot at present talk of good outcome of this system; especially in the lower secondary school education since the inception of the programme.

Teacher curriculum revitalization principles agitates for the following among others

1. Professionalism: Teachers are required to registered under the Teachers Registration Council of Nigeria (TRCN) and the minimum qualification is National Certificate of Eduaction (NCE).

2. Increment in salaries

3. Indigenous values/needs: Teacher preparations should be geared towards indigenous values and needs

\section{THE TEACHER AND THE REVITALIZED CURRICULUM}

A teacher is a person who consciously and deliberately organizes systematic instructions for learners/students. That is, a teacher imparts knowledge to others. A teacher therefore supposes to be the one that should exclusively be regarded as honorable members of the society. This is because teachers are the molders of life and character of the young citizens through various training programmes in our schools; they occupy strategic positions in curriculum planning, development, and implementation (Dada, 1999).

Therefore, for functional educational system in Nigeria; teachers should be recognized as a vital consolidating factor sustaining the position of Nigerian educational system. The curriculum is being interpreted, moderated and disseminated by the teacher. In terms of their preparation, the interest and attitudes of teachers towards effective, functional and vibrant outcome or productivity is worthy of serious examination. By the launching of the Universal Primary Education (U.P.E.) scheme in 1976, Nigerians had six years to prepare for the next stage which was the launching of the junior secondary school scheme. The curriculum at this stage is more diversified and emphases are placed on the teaching of prevocational subjects in addition to two Nigerian languages. Therefore, the comprehensive nature of the secondary school programme necessitates adequate preparation of teachers for effective productivity (Osokoya 1997). Teachers' productivity is an important factor in educational development and also a vital factor in consolidating the Nigerian educational system. Training and re-training of teachers determines the quality of the out-put and no nation can progress without the effective development and management of teachers.

A teacher is a person who consciously and deliberately organizes systematic instructions for learners. Therefore, her competence, effectiveness and efficiency in the teaching of the subject constitute a critical factor in the success of the Nigeria educational system. Training and re-training of teachers as a pre-condition for functional educational system in Nigeria is very necessary in Nigeria for effective teaching productivity

Re-training of teachers on the job is to enhance functional educational system in Nigeria and to improve the process of teaching and learning is very important in quality education. This is the process of training and development aims at increasing the ability of individuals and groups to contribute to organizational effectiveness. While re-training is designed to improve the teacher's skills, development programmes are designed to educate employees beyond the requirements of their present position so that they will be prepared for promotion and be able to take a broader view of their role in the organization.

The need to train and to re-train teachers who are being promoted is self-evident, every job usually require training in new skills. For effective productivity of teachers and consolidation of Nigeria educational system, teachers must be effectively trained and retrained (Akinbote, 1999). Training and re-training of teacher is in the ethics of the profession. This will improve methods, skills, and procedures to enhance their outputs, efficiency and productivity. Over the years when teachers were employed in large number, induction trainings were organized for them by the Teaching Service Commission but of recent, employment is scarcely and secretly done and hence the few newly employed teachers do not undergo any form of induction.

\section{CURRICULUM REVIEW AND INNOVATION}

Gidado (2000) observed and identified "inappropriate and irrelevant curriculum" as a major factor hindering the achievement of educational goals. Dada (1999) advocated for curriculum innovation, he said "when curriculum is not achieving what is expected to achieve and when the conditions for which a curriculum was established have changed considerably, then achieving qualitative teaching outcome will be hindered" 
(pp. 105). It should be realized that basic education must be tailored towards meeting the needs of the learner and the community in which he/she lives. Teaching and learning will not count much, if it cannot equip the beneficiaries with skills for lifelong learning and the survival of the educational system in Nigeria. Therefore, the mathematics education curriculum should be reviewed and enriched in order to integrate the learner into the community rather than to alienate the learner from the community. Hence, the urgent need to review and enrich curriculum to ensure that they meet individual, community and nation needs as well as consolidating the educational system. Enriching curriculum for functional and qualitative teaching outcome will bring new challenges and improvement to technological advancement that is related to teaching skills.

Reviewing included in the curriculum should include research development; research has not been given its well deserved attention in the area of curriculum development and implementation. Efforts must be made to accord priority to research as a catalyst for change and teachers' effectiveness and productivity in teaching every subject. These and other factors will help in consolidating the educational system of the nation.

\section{JUSTIFICATION TO REVITALIZE MATHEMATICS EDUCATION PROGRAMME IN TERTIARY INSTITUTIONS IN NIGERIA}

There is no doubt about the fact that there are many factors currently bedeviling Mathematics education in Nigeria including problem of quality assurance, insufficient funding, lack of personnel, poor facilities, lack of commitment by government, poor supervision, faulty selection process and poor mathematics education curriculum.

In view of the above highly challenging situation, it is, however, very pertinent and justifiable to revitalize mathematics education programme for would-be teachers in tertiary institutions in Nigeria to adequately impart in them the needed skills, knowledge and competencies to effectively and efficiently fit into teaching activities.

To revitalize mathematics education programme in tertiary institutions, a very sound mathematics education programme which is equipment intensive is required. The needed equipment such as numerous state of the art teaching/instructional and multimedia should be made available in the class room environment in all departments in tertiary institutions in order to graduate qualitative teachers who will fit into the teaching learning process of the $21^{\text {st }}$ century. The issue of qualified lecturers must also be considered for effective and fruitful running of mathematics education preparation programme.

\section{CONCLUSION}

The purpose of mathematics education is to produce more effective, efficient and highly motivated teachers to tackle the onerous task of helping someone to learn. Mathematics education as a seamless continuum consisting of three stages initial teacher education, induction and continuing professional development. The contemporary teacher in Nigeria is bedeviled with myriad of problems which must be tackled to enhance social, political and economic developments of the nation.

\section{RECOMMENDATIONS}

Based on the above discussions, the following are recommended for the revitalization of teacher for the better achievement of teaching learning process and performance in Nigeria.

The idea behind the selection and admission into mathematics education programmes in our universities should be revisited. The would be teachers or candidate to be enlisted for Mathematics education programme should be those how have the passion for teaching, who chose the career by choice and not by chance, not candidate who sole aim are to study another course but seconded to mathematics education because they don't meet the requirement for the course they originally applied.

There is need for adequate teachers at all levels both in quality and quantity. The various institutions saddled with the development of a virile mathematics education programmes should search and select the best brains not drop-outs.

There is no doubt the fact that teachers produce by the so called Nigeria NTI are incomparable to those who attended conventional university for the attainment of e.g. PGDE. Therefore, the post-graduate diploma in education (PGDE) and the Nigeria Certificate in education (NCE) run by the National Teachers institute should be overhauled A commission or agency specifically for teachers should be established. The governments 
at all levels should provide adequate facilities and infrastructure for mathematics education to meet the requirements of global best practices. The departments of supervision in both federal and states ministries of education should rise up to their responsibilities to enhance quality assurance.

\section{Disclosure statement}

No potential conflict of interest was reported by the authors.

\section{Notes on contributors}

Tella Adedeji - University of Ibadan, Science and Technology Education Department, Ibadan, Nigeria.

\section{REFERENCES}

Achuonye K. A. (2010). A comparative study of problem-based and lecture-based learning in secondary school students' motivation to learn science. International Journal of Science and Technology Education Research, 1(6), 126-131.

Akinbote, O. (1999). NCE Teachers Education Programme for Nigerian Primary Schools; Expectations for the 21st century. Teaching and Teacher's Preparation in the 21st century, 5(2), 9-12.

Amaele, S., \& Amaele, P. E. (2003). Mathematics education in contemporary society. Ogbomosho: Bobolink Media Print.

Dada (1999). The Teacher and the Curriculum. Ibadan: Tejama Enterprises.

Fatile (2005). Teachers' Areas of Interest: Its Implications on Students' Performance in English Language. Unpublished Research Project (B.A. Ed.); ACE., Ondo.

Federal Ministry of Education. (2004). National Policy on Education. Abuja: Federal Ministry of Education.

Nakpodia, E. D., \& Urien, J. (2011). Mathematics education in Nigeria: Challenges to Educational Administrators in the 21st Century. Pakistan Journal of the Social Sciences, 6(5), 359-356.

Okeke, B. S. (2004). Teaching in Nigeria: The Bureaucracy and Professionalism. Enugu: Mercury International Publishing.

Okorosaye -Orubite, A. K. (1990). Factors Responsible for Educational Under development in Rivers State: A Historical Perspective (Ph.D. Dissertation) (Educational Foundation) University of Port Harcourt.

Osokoya (1997). 6-3-3-4 Education in Nigeria; Issues, History, Strategies and problems. Ibadan: Laurel edu. Publisher.

Oyedeji, O. (2006). The concept of teacher education, in Nigeria, Departmental Study manual, Department of Curriculum Studies and Instructional Technology, Olabisi Onabanjo Unversity, Ado-Iwoye.

Paulley, F. G. (2010). Mathematics education and national development in Nigeria, 1842-2009. An Unpublished Ph.D Thesis, Faculty of Education, University of Port Harcourt, Choba. The journal, the potholes and the patches. In international journal by global educators for all initiative. Global voive of educators. June 2012.

Rogers (1973). In-Service Training: Structure and Content. London: Ward Lock, Edu Press Ltd.

Sofoyeke (2001). Major Current Issues and Policy Options in the Management of Teachers. Nigerian Journal of Educational Productivity and Contemporary Issues, (3), 127-134.

Tella, S. (2004). Visualising Future Foreign Language Education: From Revision and Supervision to Vision. In Mäkinen, K., Kaikkonen, P. \& Kohonen, V. (eds.) Future Perspectives in Foreign Language Education. Oulun yliopiston kasvatustieteiden tiedekunnan tutkimuksia 101, 71-98. (A graphic presentation of this article is at http://www.helsinki.fi/ tella/vision.html) 